\title{
A Study of Prevalence of Obesity in Patients of Bronchial Asthma Attending The Chest Department At Rims,Imphal,Manipur.India.
}

\author{
Dr.TamarPaley ${ }^{1}$,Dr.HaorongbamSunanda ${ }^{2}$,Dr.MoirangthemSeilaja ${ }^{3}$,Dr.ChristyT \\ ongbram ${ }^{4}$,Dr.Irom Ibungo Singh ${ }^{5}$, Dr.Vikas Agarwal ${ }^{6}$. \\ Department of Respiratory Medicine,Regional Institute of Medical Sciences,Imphal,Manipur.India.
}

\begin{abstract}
:
Objective: To study the prevalence rate of obesity in patients of bronchial asthma attending the chest department at Regional Institute of Medical Sciences,Imphal,Manipur.India.

Methods: In a cross-sectional study, I recruited patients with age more than 18 years and older with confirmed bronchial asthma diagnosis at Respiratory Medicine department,RIMS,Imphal,Manipur.Nutritional status was classified by body mass index (BMI).

Result: 150 patients were included in this study.Mean age was $35 \pm 1.24$ years and there were $82(54.7 \%)$ female patients. Among female, asthma was more common in housewife (30.7 \%).Mean BMI was $26.87 \pm 4.18$ and $60(40.00 \%)$ were classified as normal weight,49 patients $(32.67 \%)$ as overweight and 41 patients (27.33 $\%)$ as obesity.
\end{abstract}

Conclusion: The prevalence rate of obesity in this study was $27.33 \%$.Female asthma patients were more likely to be obese than male asthma patients.

Keywords: Obesity,Body Mass Index.

\section{Introduction}

Asthma is one of the most common chronic diseases globally and currently affects approximately 300 million individuals. According to National Family Health Survey - 2 (NFHS-2) report, the estimated prevalence of asthma in India is 2468 per 1,00,000 population. The prevalence among male was slightly higher than among females. Many factors contribute to the risk of developing asthma that include family history of atopic disorders, diet, indoor and outdoor allergens, viral infections, infant feeding habits, passive smoking, obesity and exposure to environmental dusts. This study was conducted to find out the relationship between obesity and asthma as certain mediators such as leptins which are raised in obese patients, may affect airway function and increase the likelihood of asthma development ${ }^{7}$ and hypercholesterolemia is also a potential risk factor for asthma independent of obesity. Also, obesity alone is found to be an important risk factor for asthma, particularly in women and asthmatic patients show an atherogenic lipid profile which could also increase the risk of cardiovascular disease.

Obesity is defined as a state of excess adipose tissue mass. The most widely used method to gauge obesity is the Body Mass Index (BMI) which is equal to weight $/ \mathrm{height}^{2}$ (in $\mathrm{kg} / \mathrm{m}^{2}$ ).

Table A: Body mass index and its references

\begin{tabular}{|l|l|}
\hline Body mass index $\left(\mathrm{kg} / \mathrm{m}^{2}\right)$ & References \\
\hline$<18.5$ & Underweight \\
\hline $20-24.9$ & Healthy \\
\hline $25-29.9$ & Overweight \\
\hline $30-34.9$ & Obese \\
\hline $35-39.9$ & Severely obese \\
\hline$>40$ & Extreme obesity \\
\hline
\end{tabular}

Most prospective studies show that obesity is a risk factor for asthma and have found a positive correlation between baseline body mass index and the subsequent development of asthma. Furthermore, several studies suggest that whereas weight gain increases the risk of asthma, weight loss improves the course of the illness. Different factors could explain this association. Obesity is capable of reducing pulmonary compliance, lung volumes, and the diameter of peripheral respiratory airways as well as affecting the volume of blood in the lungs and the ventilation-perfusion relationship. Furthermore, the increase in the normal functioning of adipose tissue in obese subjects leads to a systemic proinflammatory state, which produces a rise in the serum concentrations of several cytokines, the soluble fractions of their receptors, and chemokines. ${ }^{10}$ 


\section{Aims And Objects}

The aim of this study is to find out the prevalence rate of Obesity in patients of Bronchial Asthma attending the Respiratory Medicine Department at RIMS, Imphal.

\section{Materials And Methods}

It is a cross-sectional study conducted in the Department of Respiratory Medicine, Regional Institute of Medical Sciences, Imphal, Manipur for a period of two years from October 2013 to September 2015.Inclusion criteria: Male and female patients of more than 18 years of age with symptoms of breathlessness, wheeze, cough and chest tightness in whom there is more than $12 \%$ or more and $200 \mathrm{ml}$ increase in Forced Expiratory Volume in 1 minute (FEV1), 15 min after an inhaled short - acting $\beta 2$ - agonist is diagnosed as a case of asthma and was included in the study.

Exclusion criteria: Patients with co-morbid conditions such as hypertension, diabetes mellitus, hypercholesterolemia, coronary artery disease and alcoholic liver disease and uncooperative patients. Sample size and sampling: Taking prevalence rate of $6.7 \%{ }^{16}$ sample size was calculated as Sample size $=z^{2} \mathrm{x} \mathrm{pg} / \mathrm{e}^{2}$ $=3.9 \times 6.7 \times 93.3 / 4^{2}=153$ where $\mathrm{z}=1.96, \mathrm{p}=$ percentage, $\mathrm{g}=(100-\mathrm{p}), \mathrm{e}=$ standard error. In this study, a sample of 150 asthma patients attending Department of Respiratory Medicine, R.I.M.S. Imphal, Manipur was included by consecutive sampling.

Study variables were age, sex, religion, occupation, address, weight, height, BMI, marital status, duration of asthma.Study tools: 1. Spirometer: Model- RMS Helios 701. Serial number: HELS/112254/401. Manufacturer: Recorders \& Medicare Systems. 2. Others: Nebulizer (HANDYNEB, Nulife Global Medical Devices Pvt. Ltd. India), Nebulisation mask, salbutamol $2.5 \mathrm{mg}$ respules, Weighing machine (Crown Ramon Surgical Co. India), Measuring scale in centimetre/metre. Written informed consent was taken from each participant before the start of the study.

Those patients who were willing and volunteered to participate in this study were subjected to thorough general physical and clinical examinations. Detailed histories regarding the nature of symptoms like breathlessness, cough, sputum production, wheeze, chest tightness, etc. were obtained. History of allergy, history of smoking, history of alcoholism and history of previous similar illness were also noted. Height, weight and the vital signs including blood pressure, pulse rate and temperature were measured. Chest $\mathrm{x}$-ray and ECG were taken. Clinical examination of the respiratory system was carried out. Laboratory tests: 1 . Routine blood tests were done.

2. Measurement of obesity: By using the body mass index (BMI) according to World Health Organisation (WHO) criteria, the nutritional status of the patients were calculated as BMI=weight (in $\mathrm{Kg}$ )/height ${ }^{2}$ (in metre) Analysis: Analysis was done with IBM SPSS Version 16. Descriptive statistics like mean and percentages were used. Chi-square test was used for analysis. Probability of p-value $<0.05$ was taken as significant. Ethical issue: The study was conducted with due approval of the Institutional Ethics Committee. Written informed consent was taken from the individual participants.

The results of this study are as follows:

\section{Results And Observation}

Table 1: Age distribution of the respondents

\begin{tabular}{|l|l|l|}
\hline Age in years & Number & Percentage \\
\hline $0-10$ & 0 & 0 \\
\hline $11-20$ & 11 & 7.3 \\
\hline $21-30$ & 45 & 30.0 \\
\hline $31-40$ & 46 & 30.7 \\
\hline $41-50$ & 30 & 20.0 \\
\hline $51-60$ & 14 & 9.3 \\
\hline$>60$ & 4 & 2.7 \\
\hline Total & $\mathbf{1 5 0}$ & $\mathbf{1 0 0 . 0}$ \\
\hline Mean \pm SD & $35 \pm 1.24$ & \\
\hline
\end{tabular}

Majority of the asthma patients aged 31 years to 40 years which accounted for $60.7 \%$. Mean age was 35 years with a standard deviation of 1.24 years.

Table 2: Sex distribution of the respondents

\begin{tabular}{|l|l|l|}
\hline Sex & Number & Percentage \\
\hline Male & 68 & 45.3 \\
\hline Female & 82 & 54.7 \\
\hline Total & $\mathbf{1 5 0}$ & $\mathbf{1 0 0 . 0}$ \\
\hline
\end{tabular}


Female constitutes majority of the asthma patients in this study which accounted for $54.7 \%$ of the cases as shown in table 2 .

Table 3: Distribution of the respondents by address

\begin{tabular}{|l|l|l|}
\hline Address & Number & Percentage \\
\hline Imphal West & 72 & 48.0 \\
\hline Imphal East & 26 & 17.3 \\
\hline Thoubal & 20 & 13.3 \\
\hline Bishenpur & 16 & 10.7 \\
\hline Churachandpur & 5 & 3.3 \\
\hline Senapati & 4 & 2.7 \\
\hline Tamenglong & 4 & 2.7 \\
\hline Outside Manipur & 3 & 2.0 \\
\hline Total & $\mathbf{1 5 0}$ & $\mathbf{1 0 0 . 0}$ \\
\hline
\end{tabular}

Most of the patients with asthma attending Department of Respiratory Medicine were from Imphal West (48\%) followed by Imphal East (17.3\%) and Thoubal (13.3\%) as shown in table 3.

Table 4: Distribution of the respondents by religion

\begin{tabular}{|l|l|l|}
\hline Religion & Number & Percentage \\
\hline Hindu & 106 & 70.7 \\
\hline Christian & 24 & 16.0 \\
\hline Muslim & 20 & 13.3 \\
\hline Total & $\mathbf{1 5 0}$ & $\mathbf{1 0 0 . 0}$ \\
\hline
\end{tabular}

Table 4 shows that majority of the asthma patients were Hindu (70.7\%) followed by Christian (16.0\%) and Muslim (13.3\%).

Table 5: Distribution of the respondents by occupation

\begin{tabular}{|l|l|l|}
\hline Occupation & Number & Percentage \\
\hline Housewife & 46 & 30.7 \\
\hline Student & 39 & 26.0 \\
\hline Business & 21 & 14.0 \\
\hline Farmer & 20 & 13.3 \\
\hline Teacher & 8 & 5.3 \\
\hline Shopkeeper & 7 & 4.7 \\
\hline Army & 6 & 4.0 \\
\hline Govt. Employed & 3 & 2.0 \\
\hline Total & $\mathbf{1 5 0}$ & $\mathbf{1 0 0 . 0}$ \\
\hline
\end{tabular}

Most of the asthma patients were housewives (30.7\%) followed by student (26\%), business (14\%) and farmer $(13.3 \%)$ as shown in table 5 .

Table 6: Distribution of the respondents by marital status

\begin{tabular}{|l|l|l|}
\hline Marital status & Number & Percentage \\
\hline Married & 106 & 70.7 \\
\hline Unmarried & 44 & 29.3 \\
\hline Total & $\mathbf{1 5 0}$ & $\mathbf{1 0 0 . 0}$ \\
\hline
\end{tabular}

Majority of the asthma patients were married which accounted for 70.75 of cases as shown in table 6 .

Table 7: Distribution of the respondents by weight and height

\begin{tabular}{|l|l|}
\hline Variable & Mean \pm SD \\
\hline Weight $(\mathrm{Kg})$ & $63.28 \pm 9.62$ \\
\hline Height $($ Meter $)$ & $1.5 \pm 0.07$ \\
\hline
\end{tabular}

The mean weight of the respondents is $63.28 \mathrm{~kg}$ with a standard deviation of 9.62 and the mean height is 1.5 meters with a standard deviation of 0.07 meter.

Table 8: Distribution of the respondents by BMI

\begin{tabular}{|l|l|l|}
\hline BMI & Number & Percentage \\
\hline$<18.5$ (underweight) & 0 & 0.0 \\
\hline $18.5-24.9$ (normal) & 60 & 40.00 \\
\hline $25-29.9$ (overweight) & 49 & 32.67 \\
\hline$\geq 30$ (obese) & 41 & 27.33 \\
\hline
\end{tabular}


A Study of Prevalence of Obesity In Patients of Bronchial Asthma Attending The Chest Department..

\begin{tabular}{|l|l|l|}
\hline Total & 150 & 100.0 \\
\hline Mean \pm SD & $26.87 \pm 4.18$ \\
\hline
\end{tabular}

Majority of the asthma patients have normal BMI (40.0\%) as shown in table 8. Forty one cases $(27.33 \%)$ were found to be obese so, prevalence of obesity among asthma patients in this study is $27.33 \%$. Mean BMI was 26.87 with a standard deviation of 4.18

Table 9: Distribution of the respondents by duration of asthma

\begin{tabular}{|l|l|l|}
\hline Duration of asthma & Number & Percentage \\
\hline $0-5$ years & 58 & 38.7 \\
\hline $5.1-10$ years & 75 & 50.0 \\
\hline$>10$ years & 17 & 11.3 \\
\hline Total & $\mathbf{1 5 0}$ & $\mathbf{1 0 0 . 0}$ \\
\hline Mean \pm SD & $\mathbf{7 . 0 9} \pm \mathbf{4 . 0 3}$ \\
\hline
\end{tabular}

Table 9 shows that majority of the patients had asthma for more than 5 years to 10 years which accounted for $50 \%$ of cases.

Table 10: Relationship between age and obesity in asthma patients

\begin{tabular}{|c|c|c|c|c|}
\hline \multirow{2}{*}{ Age in years } & \multicolumn{2}{|c|}{ Obesity } & \multirow{2}{*}{ Total (\%) } & \multirow{2}{*}{ Chi-square test } \\
\hline & No $(\%)$ & Yes $(\%)$ & & \\
\hline $11-20 *$ & $11(100)$ & $0(0.0)$ & $11(100.0)$ & \multirow{7}{*}{$\begin{array}{c}\text { Value }=7.04 \\
\text { p- } 0.07\end{array}$} \\
\hline $21-30^{*}$ & $35(77.8)$ & $10(22.2)$ & $45(100.0)$ & \\
\hline $31-40$ & $25(54.3)$ & $21(45.7)$ & $46(100.0)$ & \\
\hline $41-50$ & $24(80.0)$ & $6(20.0)$ & $30(100.0)$ & \\
\hline 51-60\# & $10(71.4)$ & $4(28.6)$ & $14(100.0)$ & \\
\hline$>60 \#$ & $4(100.0)$ & $0(0.0)$ & $4(100.0)$ & \\
\hline Total & 109 (72.67) & $41(27.33)$ & $150(100.0)$ & \\
\hline
\end{tabular}

$* \& \#$ are clubbed together for analysis

Obesity among asthma patients tends to increase with age till age group 31-40 years then again decrease with older age group as shown in table 10. This finding is found to be statistically insignificant $(\mathrm{p}>0.05)$.

Table 11: Relationship between sex and obesity in asthma patients

\begin{tabular}{|l|l|l|l|l|}
\hline Sex & \multicolumn{2}{|c|}{ Obesity } & Total (\%) & Chi-square test \\
& No $(\boldsymbol{\%})$ & $(\%)$ & & \\
\hline Male & $56(82.3)$ & $12(17.6)$ & $68(100.0)$ & Value=5.38 \\
\cline { 1 - 4 } Female & $53(64.6)$ & $29(35.4)$ & $82(100.0)$ & p-value $=0.01$ \\
\cline { 1 - 4 } Total & $\mathbf{1 0 9}(\mathbf{7 2 . 6 7})$ & $\mathbf{4 1}(\mathbf{2 7 . 3 3})$ & $\mathbf{1 5 0}(\mathbf{1 0 0 . 0})$ & \\
\hline
\end{tabular}

Table 11 shows that female asthma patients were more obese then male patient (35.4\% vs $17.6 \%)$. This finding is found to be statistically significant $(\mathrm{p}<0.05)$.

Table 12: Relation between marital status and obesity in asthma patients

\begin{tabular}{|c|c|c|c|c|c|}
\hline \multirow[t]{2}{*}{ Marital status } & \multicolumn{2}{|c|}{ Obesity } & \multirow{2}{*}{$(\%)$} & \multirow{2}{*}{ Total $(\%)$} & \multirow{2}{*}{ Chi-square test } \\
\hline & No $(\%)$ & Yes $(\%)$ & & & \\
\hline Married & $72(67.9)$ & $34(32.1)$ & & $106(100.0)$ & Value $=6.43$ \\
\hline Unmarried & $37(84.0)$ & $7(15.9)$ & & $44(100.0)$ & p-value $=0.04$ \\
\hline Total & 109 (72.67) & $41(27.33)$ & & $150(100.0)$ & \\
\hline
\end{tabular}

Married patients tend to be significantly $(\mathrm{p}<0.05)$ more obese than unmarried patients as shown in table 12 .

Table 13: Relation between duration of asthma and obesity in asthma patients

\begin{tabular}{|c|c|c|c|c|c|}
\hline \multirow{2}{*}{$\begin{array}{ll}\begin{array}{l}\text { Duration } \\
\text { asthma }\end{array} & \text { of } \\
\end{array}$} & \multicolumn{2}{|c|}{ Obesity } & \multirow[b]{2}{*}{$(\%)$} & \multirow{2}{*}{ Total (\%) } & \multirow{2}{*}{ Chi-square test } \\
\hline & No $(\%)$ & Yes $(\%)$ & & & \\
\hline $0-5$ years & 41 (70.6) & $17(29.4)$ & & $58(100.0)$ & \multirow{4}{*}{$\begin{array}{l}\text { Value }=2.78 \\
\text { - } \text {-value }=0.24\end{array}$} \\
\hline $5.1-10$ years & $54(45.3)$ & $21(54.7)$ & & $75(100.0)$ & \\
\hline$>10$ years & $14(82.4)$ & $3(17.6)$ & & $17(100.0)$ & \\
\hline Total & $109(72.67)$ & $41(27.33)$ & & $150(100.0)$ & \\
\hline
\end{tabular}

Obesity is less among patients with asthma more than 10 years but the finding is statistically insignificant ( $p>0.05)$ as shown in table 13. 


\section{Discussion}

Most prospective studies show that obesity is a risk factor for asthma and have found a positive correlation between baseline body mass index and the subsequent development of asthma. ${ }^{10}$ This study was conducted in the Department of Respiratory Medicine, RIMS, Imphal during October 2013 to September 2015 including 150 consecutive patients of asthma to find out the prevalence of obesity among the asthma patients.

More than half of the patients were females (54\%) and this finding is consistent with studies by Agrawal S et $\mathrm{al}^{11}$, Forte GC et $\mathrm{al}^{32}$ and Sposato B et $\mathrm{al}^{28}$. And most of these females were housewives which may have been due to greater exposure to fumes and dust at home where chulas are used for cooking. Most asthma patients in this study were from age group 21-40 years. Mean age of the asthma patients was 35 years with a standard deviation of 1.24 years. But in the study by Tavasoli $\mathrm{S} \mathrm{et} \mathrm{al}{ }^{30}$ and Forte GC et al ${ }^{32}$ mean age was higher ie, 46.5 years and 51.1 years respectively. Gonzalez Barcala $\mathrm{FJ}$ et al ${ }^{17}$ concluded that obesity was associated with a higher prevalence of asthma in young children but not in adolescents. This similar finding is observed in this study, none of the adolescents were obese. Most of the patients were from Imphal West district, Hindu and married.

Majority of the asthma patients weighted normal (40.0\%) followed by overweight (32.67\%) and obese (27.33\%). The prevalence rate of obesity in this study is $27.33 \%$. Mean BMI was 26.87 with standard deviation of 4.18. The following are various studies of obesity prevalence in asthma

Table 14: Relation between duration of asthma and obesity in asthma patients

\begin{tabular}{|l|l|}
\hline Studies & Prevalence \\
\hline Gennuso J et al $^{21}$ & $30.6 \%$ \\
\hline Tavasoli S et al $^{30}$ & $29.3 \%$ \\
\hline Forte GC et al $^{32}$ & $29.0 \%$ \\
\hline Nathell L et al $^{25}$ & $20.7 \%$ \\
\hline Behren JV et al $^{19}$ & $13.0 \%$ \\
\hline Kajbaf TZ et al $^{16}$ & $6.7 \%$ \\
\hline Bibi H et al $^{13}$ & $5.0 \%$ \\
\hline
\end{tabular}

From the above table, it is seen that the studies conducted by Gennuso $\mathrm{J}$ et $\mathrm{al}^{21}$, Tavasoli $\mathrm{S}$ et $\mathrm{al}^{30}$ and Forte $\mathrm{GC}$ et $\mathrm{al}^{32}$ had similar findings with this study. Other studies had lower prevalence compared to this study. Obesity among asthma patients tends to increase with age till age group 31-40 years then decrease with advancing age but this is found to be statistically insignificant. Female asthma patients were significantly more obese than male patients in this study (35.4\% vs $17.6 \%)$. This finding is supported by Tavasoli $\mathrm{S}$ et $\mathrm{al}^{30}$ where mean body mass index of females with asthma was significantly higher than males. Similar findings that female asthma patients were more obese were observed in the studies by Mishra $\mathrm{V}^{14}$, Veqa-Robledo GB et $\mathrm{al}^{24}$, Shaheen $\mathrm{SO}$ et $\mathrm{al}^{33}$ and Mathew $\mathrm{AC}$ et $\mathrm{al}^{34}$.

Half of the patients had asthma for more than 5 years to 10 years. Mean duration of asthma was 7 years. Obesity was seen more in patients suffering from asthma for more than 5 years to 10 years. Obesity was also seen in asthmatic patients having duration of illness of 0 to 5 year. So,in the middle and early stage of disease,there is chance of obesity. Obesity is less among patients with asthma more than 10 years but the finding is statistically insignificant $(\mathrm{p}<0.05)$.

\section{Conclusion}

A cross sectional study was conducted to assess the prevalence of obesity among 150 Bronchial Asthma patients attending the Chest Department of RIMS, Imphal from October 2013 to September 2015. This study found out that asthma patients were more common in the age group of 21-40 years and also more among females. Among females asthma was more common in housewives. Married people were more likely to have asthma in this study. The prevalence rate of obesity in this study was $27.33 \%$. Female asthma patients were more likely to be obese than male asthma patients. And married asthma patients tend to be more obese than unmarried asthma patients. Duration of asthma had no relation with obesity in this study.

\section{Summary}

A cross sectional study was conducted to assess the prevalence of obesity among 150 Bronchial Asthma patients attending the Chest Department of RIMS, Imphal from October 2013 to September 2015. The type of sampling used was consecutive sampling. This study used Body Mass Index (BMI) according to World Health Organization (WHO) criteria as the tool for measuring obesity. Analysis was done with IBM SPSS Version 16 and data were described using mean and percentages. Chi-square test was used for test of significance. Ethical approval was taken before the study from the institutional ethics committee. Informed consent was taken from all the participants. 
This study found out that asthma patients were more common in the age group of 21-40 years and also more among females. Among females, asthma was more common among housewives. Married people were more likely to have asthma in this study. The prevalence rate of obesity in this study was $27.33 \%$. Female asthma patients were more likely to be obese than male asthma patients. This finding is consistent with many studies. $^{30,32}$ And married asthma patients tend to be more obese than unmarried asthma patients. Duration of asthma had no relation with obesity in this study.

Obesity has many consequences like myocardial infarction, stroke, hypertension, diabetes mellitus, obstructive sleep apnea etc. In order to stop these consequences there is a need to search for causes of obesity and its effects, including obesity in asthma. It is also recommended to perform better studies with controls and with bigger sample size to support this finding.

\section{References}

[1]. Masoli M, Fabian D, Holt S, Beasley R. The global burden of asthma: executive summary of the GINA Dissemination Committee report. Allergy 2004;59(5):469-78.

[2]. Beasley R. The Global of Asthma Report, Global Initiative For Asthma (GINA). Available from http://www.ginasthma.org 2004. Accessed September 16, 2015.

[3]. Andrea J, Apter, Weiss ST. Asthma: Epidemiology.In: Fishman AP, Elias JA, Fishman JA, Grippi MA, editors. Senior RM, Pack AI, co-editors.Fishman's Pulmonary Diseases and Disorders. $4^{\text {th }}$ ed. United States of America: McGraw-Hill; 2008. p.795-7.

[4]. Li JTC, O’Connell EJ. Clinical Evaluation of Asthma.Ann Allergy Asthma Imunol 1996;76(1):1-14.

[5]. Capro RO, Morris AH, Gardner RM. Reference spirometric values using techniques and equipment that meets ATS recommendations. Am Rev Respir Dis 1981;123(6):659-94.

[6]. NAEPP: Executive Summary of the NAEPP Expert Panel Report: Guidelines for the Diagnosis and Management of Asthma: Update on Selected Topics, Bethesda, MD, NIH, 2002. Available at: www.vidyya.com/2pdfs/06execsumm.pdf. Accessed september 10, 2015

[7]. Delgado J, Barranco P, Quirce S. Obesity and Asthma. J Investig Allergol Clin Immunol 2008;18(6):422-5.

[8]. Jeffrey SF, Elefteria MF. Biology of obesity. In: Fauci AS, Kasper DL, Longo DL, editors. Harrison's principles of internal medicine. $17^{\text {th }}$ ed. New York: Mc Graw Hill; 2008. p. 462-8.

[9]. World Health Organisation: Obesity and Overweight. Factsheet N311[updated march 2013] Available from http/www.who.int/mediacentre/factsheets/fs311/en. Accessed September 15, 2015

[10]. Dixon AE, Shade DM, Cohen RI. Effect of obesity and clinical presentation and response to treatment in asthma. J Asthma. 2006;43(7):553-8

[11]. Agrawal S, Pearce N, Ebrahim S. Prevalence and risk factosr for self-reported asthma in an adult Indian population; a crosssectional survey. Int J Tuberc Lung Dis 2013;17(2):275-82.

[12]. Camargo CA Jr, Weiss ST, Zhanq S, Willet WC, Speizer FE. Prospective study of body mass index, weight change,and risk of adult-onset asthma in women. Arch Intern Med 1999;159(21):2582-8.

[13]. Bibi H, Shoseyov D, Feigenbaum D, Genis M, Friger M, Peled R, et al. The relationship between asthma and obesity in children; is it real or a case of over diagnosis? J Asthma 2004;41(4):403-10.

[14]. Mishra V. Effect of obesity on asthma among adult Indian women. Int J Obes Relat Metab Discrd 2004;28(8):1048-58.

[15]. Cassol VE, Rizzato TM, Teche SP, Basso DF, Centenaro DF, Maldonado M, et al. Obesity and its relationship with asthma prevalence and severity in adolescents from southern Brazil. J Asthma 2006;43(1):57-60.

[16]. Kajbaf TZ, Asar S, Alipoor MR. Relationship between obesity and asthma symptoms among children in Ahvaz,Iran: a cross sectional study. Italian Journal of Pediatrics 2011;37(1):1186-98

[17]. Gonzalez-Barcala FJ, Peterga S, Perez-Castro T, Sampedro M, Sanchez-Lastres J, San Jose Gonzalez MA, et al. Obesity and asthma: An association modified by age. Allergol Immunopathol (Madr) 2013;41(3):176-80.

[18]. Figueroa-Munoz JI, Chinn S, Rona RJ. Association between obesity and asthma in 4-11 year old children in the UK. Thorax 2001;56(2):133-7.

[19]. Behren JV, Lipsett M, Horn-Rose PL, Delfino RJ, Gilliland F, McConnell R, et al. Obesity, waist size and prevalence of current asthma in the California Teachers Study cohort. Thorax 2009;64(10):889-93.

[20]. Black MH, Smith N, Porter AH, Jacobsen SJ, Koebnick C. Higher prevalence of obesity among children with asthma. Obesity (Silver Spring) 2012;20(5):1041-7.

[21]. Gennuso J, Epstein LH, Paluch RA, Cerny F. The relationship between asthma and obesity in urban minority children and adolescents. Arch Pediatr Adolesc Med 1998;152(12):1197-200.

[22]. Grotta MB, Cola DM, Toro A, Ribeira MA, Mazon SB, Ribeiro JD et al .Obesity increases eosinophil activity in asthmatic children and adolescents. BMC Pulmonary Medicine 2013;13(39):1-8.

[23]. Barros LL, Souza-Machado A, Correa LB, Santos JS, Cruz C, Leite M, et al. Obesity and poor asthma control in patients with severe asthma. J Asthma 2011;48(2):171-6.

[24]. Vega-Robledo GB, Valencia-Zavala MP, S Nchez-Olivas M, Vel Zquez-S Mano S, Rico-Rosilo G. Association of obesity in adults with allergic asthma. Rev Alergy Mex 2012;59(4):173-9.

[25]. Nathell L, Jensen I, Larsson K. High prevalence of obesity in asthmatic patients on sick leave. Respir Med 2002;96(8):642-50.

[26]. Tantisira KG, Weiss ST. Complex interactions in complex traits:obesity and asthma. Thorax 2001;56:164s-74s.

[27]. Badier M, Guillot C, Delpierre S. Increased asymptomatic airway hyper- responsiveness in obese individuals. J Asthma 2013;50(6):573-8

[28]. Sposato B, Scalese M, Miqliorini MG, Ricardi MP, Tosti Balducci M,Petruzzelli L, Scala R. Obesity can influence children's and adolescents' airway hyper-responsiveness differently. Multidisp Respir Med 2013;8(1):60-2.

[29]. Masumoto N, Odajima H, Shimada K, Murakami Y, Motomura C, Honjo S et al. Effect of weight reduction on respiratory function in obese children with asthma. Arerugi 2011;60(8):983-92.

[30]. Tavasoli S, Heidarnazhad H, Kazemmejad A, Miri S. Association between asthma severity and obesity in two asthma clinics in Tehran. Iran J Allergy Asthma Immunol 2005;4(4):179-83.

[31]. Fida N, Enquobahrie DA, Galaye B, Qiu C, Williams MA. Associations of Asthma with Body Mass Index and Adult Weight Change among Reproductive Age Women. J Asthma 2011;48(11):701-6. 
[32]. Fore GC, Grutcki DM, Manegotto SM, Pereira RP, Dalcin PTR. Prevalence of obesity in asthma and its relations with asthma severity and control. Rev Assoc Med Bras 2013;59(6):594-9.

[33]. Shaheen SO, Sterne JAC, Montgomery SM, Azima H. Birth weight, body mass index and asthma in young adults. Thorax 1999;54(5):396-402.

[34]. Mathew A.C, Shaijin S, David R, Ramalingam S, Srikanth K, Yunsheng M. Association between obesity and asthma among adults: A hospital bases case control study. Asian Journal of Epidemiology 2009;2(2):33-4.

[35]. Juel CTB, Ali Z, Nilas L, Ulrik CS. Asthma and obesity: does weight loss improve asthma control? a systematic review. Journal of Asthma and Allergy 2012;5(7):21-26.

[36]. Ramasamy AK, Gupta N, Kumar R. Impact of obesity on bronchial asthma in Indian population. Lung India 2014 ;31(2):121-6.

[37]. Miller MR, Hankinson J, Brusasco J. Standardisation of spirometry. Eur Respir J 2005; 26(2): 319-38. 